\title{
PARAMETERS FOR EVALUATING THE EFFECTIVENESS OF APARTMENT BUILDING MANAGEMENT
}

\author{
Stanislav Kiris ${ }^{1}$
}

\begin{abstract}
The purpose of this article is to determine the main principles for assessing the efficiency of management of an apartment building. Now in Ukraine has not yet developed a single methodology for assessing the effectiveness of apartment building management, so there are a large number of scientific approaches to the formation of such an assessment system. The organizational and economic mechanism of management of apartment buildings provides a set of interconnected components. The analysis of economic efficiency and social responsibility should consider that the management system should be aimed at achieving the following goals of apartment building management. Methodology. In the evaluation process it is necessary to calculate the value of the complex indicator of all three groups, using the weight. At this work the algorithm for evaluating the effectiveness of management of an apartment building is developed. The value of regulatory (target) indicators must be set taking into consideration the situation in the target market, taking into account the potential and intentions of the management company (manager). In the management activities of apartment buildings, evaluation of its efficiency has recently also begun to be applied by using certain criteria and assigning them points (on a 5-point scale). The main elements that have a certain numerical value in this system are the corresponding indicators. For each of them the calculation period is presented, the corresponding units of calculation and boundary conditions of the level of their values are given. The lists of criteria that must be met by the management of apartment buildings are identified. There are some negative trends of declining interest of co-owners of apartment buildings in management is described. The choice of methods of evaluation the effectiveness of apartment buildings based on form of condominiums management should be made. There are many differences in the forms of management of an apartment building, which should be counted in the new methodology for assessing the effectiveness of management. As a result of work is developed the standard scheme of an estimation of efficiency of management of apartment houses in Ukraine is developed. The sources of an initiation of assessment of the effectiveness of apartment building management are identified. The results of a survey of the association of co-owners of an apartment building (ACAB) of Dnipro in 2020 noted the following specifics which should also be taken into account in the process of assessing the effectiveness of apartment building management.
\end{abstract}

Key words: apartment building, joint property of co-owners, efficiency of apartment building management, parameters for evaluating the efficiency of apartment building.

JEL Classification: R20, R29, M19, L99

\section{Introduction}

A great value and importance for co-owners is management efficiency of existing housing stock, as its market value depends in part on the condition in general of the facilities and the level of housing and communal services provided in it. Professional managers are also directly interested in the high efficiency of housing management, as their professional reputation depends on it. (Alekseev, 2016; Moroz, 2018). The interests of homeowners and managers in terms of management efficiency

Corresponding author:

${ }^{1}$ SHEI "Ukrainian State University of Chemical Technology", Ukraine.

E-mail: spkiris@gmail.com

ORCID: https://orcid.org/0000-0001-6905-9682 coincide completely, but the criteria for this efficiency need to be clearly defined.

The principles of effective management of apartment buildings consist in achieving the appropriate management goal (a certain quality result or quality of the object at optimal costs) (Moroz, Bondarenko, Chubka, 2018). An effective apartment building management system requires the joint efforts of their co-owners and management bodies (depending on the chosen form of apartment building management). 
It should be noted that Ukraine has not yet developed a single methodology for assessing the effectiveness of apartment building management, so there are a large number of scientific approaches to the formation of such an assessment system. The vast majority of apartment building authorities aim to:

- satisfying needs of co-owners in quality services;

- carrying out current and capital repairs;

- quick response to the needs of co-owners;

- information support of co-owners;

- performance of works on improvement of housing stock, etc.

\section{The algorithm for evaluating the effectiveness}

The algorithm for evaluating the effectiveness of management of an apartment building should look like this (Figure 1).

In the evaluation process it is necessary to calculate the value of the complex indicator of all groups, using their weight. The value of regulatory (target) indicators must be set taking into consideration the situation in the target market, taking into account the potential and intentions of the management company (manager). The next stage assumes that in the process of calculating the ratio of actual and target values of indicators it is necessary to take into consideration that in the analysis of some of them the picture of target dynamics has a regressive character (reduction of indicator value is a positive trend). In this case, it should be used the inverse of the indicator, in the calculation of which the targets are divided by the actual.

Necessity to determine the weight of each indicator is due to the fact that the indicators, with the importance of assessing each of them, may have different degrees of significance in the overall assessment of the effectiveness of management of urban residential real estate. Besides, weights will allow you to set priorities in each specific period of development. The weights are set by experts for each group of indicators, with the contribution of each group of indicators is taken equal.

The organizational and economic mechanism of management of apartment buildings provides a set of interconnected components, which provide:

- achieving the ultimate management goal;

- transition from normative-tariff regulation of cost and quality of communal services provided by co-owners of an apartment house to payment of actually consumed volume of services;

- development of the scheme of interaction of local public authorities, various business entities and consumers in the process of providing services;

- reforming the financing system with an emphasis on paying consumers for management and other services, taking into account their real value;

- rational schemes of combination of available sources of financing;

- creating conditions for effective management.

For today, the situation regarding the assessment of the effectiveness of apartment building management in Ukraine provides the existence of parameters and standards of quality of housing and communal
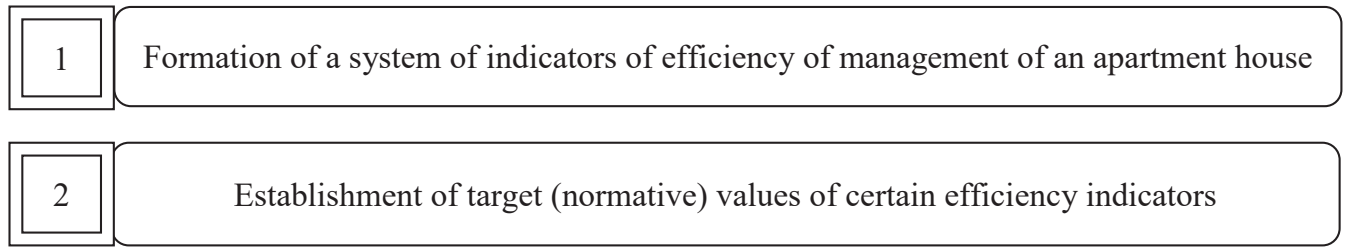

\begin{tabular}{|l|l|l|l|}
\hline 3 & Search and obtain data on the actual values of the analyzed indicators \\
\hline
\end{tabular}

\begin{tabular}{|c|c|}
\hline & $\begin{array}{c}\text { Determining the deviations of the planned indicators from the actual ones, } \\
\text { the reasons for these deviations, their ratios }\end{array}$ \\
\hline
\end{tabular}
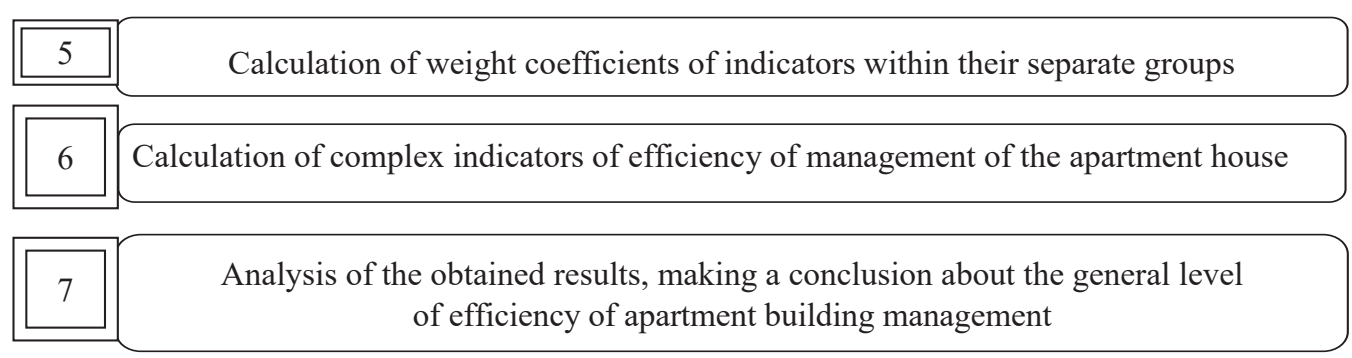

Figure 1. Algorithm for evaluating the effectiveness of apartment building management

Source: author's development 
services, normative documents, which quite clearly regulate the issues of housing and communal services. However, when it comes to the quality and efficiency of management in relation to apartment buildings, when tracking the technical or legal side of the case are left aside the system-forming elements of quality management of apartment buildings, which are not evaluated or evaluated on an intuitive level. These elements include the following:

- apartment building management can be considered from a tactical or strategic point of view, as all management plans are implemented in both the short and medium and long term (by indicating that the vast majority of administrators carry out tactical planning planning the performance of an apartment project for one year;

- in the conditions of development of the market of administrative activity by apartment houses such characteristics of management, as its reputation, openness, orientation on sustainable development, etc. start to acquire special value;

- in the context of management development in the housing sector, managers gain significant experience, use foreign experience to assess the effectiveness of management to increase their own competence and, accordingly, increase their own competitiveness in the labor market.

For the purpose of developing criteria for quality and efficiency of apartment building management, the following features of this approach to evaluation are taken into account:

- the ability to compare the effectiveness of management of apartment buildings for different forms of management, as well as governing bodies and their representatives;

- objectivity of management efficiency assessment;

- availability of data required for analysis;

- ensuring the unity of approaches to assessing the quality of management of different types of housing; - identification of management problems in different forms of management;

- involvement of co-owners in the assessment of management quality.

Consumers of the results of the obtained assessments are state local governments, co-owners of an apartment building, as well as specialists in various fields and experts. The assessment can be used as a basis for developing a more detailed list of indicators that allow us to draw conclusions about the effectiveness of apartment building management.

In general, a typical scheme for assessing the effectiveness of management of apartment buildings in Ukraine is as follows (Figure 2).

In the management activities of apartment buildings, evaluation of its efficiency has recently also begun to be applied by using certain criteria and assigning them points (on a 5-point scale):
-5 points - full responsibility with established rules and regulations (excellent quality);

- 4 points - responsibility with the rules and regulations for all major parameters (quality is considered good);

- 3 points - there is compliance with the rules and regulations only on some basic parameters (this quality is satisfactory);

- 2 points - there is a low compliance with rules and regulations (the quality of management is unsatisfactory);

- 1 point - complete non-compliance with the established requirements and criteria, these management activities are completely ineffective.

Also, the effectiveness of the management of apartment buildings can be assessed by the following criteria:

- the level of technical condition of the common property of apartment buildings, as well as the current condition of adjacent territories;

- the size and dynamics of financial and economic indicators of activity in the management of apartment buildings;

- assessment and analysis of indicators that indicate the quality of housing and communal services for co-owners of apartment buildings.

There are many questions regarding the management of a residential building, compliance with existing norms, standards, procedures and rules in practice.

The main elements that have a certain numerical value in this system are the corresponding indicators. For each of them the calculation period is presented, the corresponding units of calculation and boundary conditions of the level of their values are given. The list of criteria that must be met by the management of apartment buildings is as follows:

1. Proper condition of an apartment building (or buildings).

2. The ability of the house to conduct effective organizational and economic activities.

3. Effective economic management.

4. Established interaction with co-owners.

5. Focus on the development of the management function of an apartment building.

The first three criteria begin to be used in Ukraine, but the last two are used only by innovation managers.

\section{The negative trends of apartment building management}

In general, in Ukraine there is a negative trend of declining interest of co-owners of apartment buildings in management:

- meetings of co-owners are held very rarely usually once a year, which does not allow for effective management, taking into account the views of all participants in the process; 


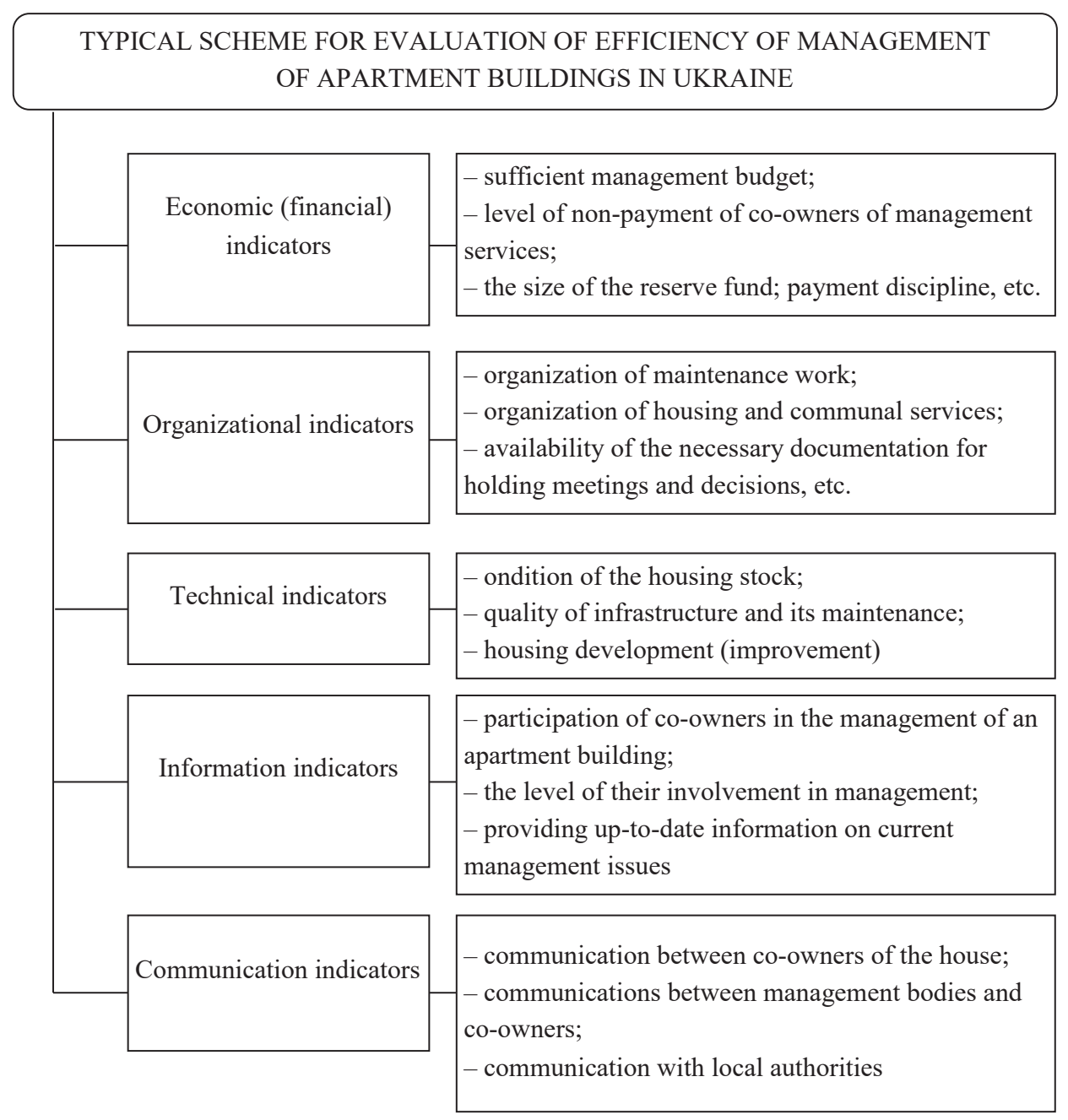

Figure 2. A typical scheme for assessing the effectiveness of management of apartment buildings in Ukraine

Source: author's development

- the interest of co-owners is mainly focused on the amount of payment for the services of the management company or the cost of utilities of the Association of co-owners of an apartment building (ACAB);

- in case of necessity of current or capital repairs there are conflict situations: if the funds of the reserve fund are used for current repairs, then the financial participation of all co-owners is necessary for capital repairs, which they mostly refuse (motivated by low income);

- there are frequent cases of lack of a common point of view on the main priority problems of an apartment building that need to be addressed as a matter of priority (for example, upper floor residents need roof repairs, but lower floor residents do not have roof leaks and believe that this cost item is not as urgent, in turn, residents of the first floor require replacement of the front door for insulation, but residents of the upper floors do not have such problems).
It should also be noted that the results of a survey of the association of co-owners of an apartment building (ACAB) of Dnipro in 2020 noted the following specifics, which, in our opinion, should also be taken into account in the process of assessing the effectiveness of apartment building management:

- the predominant contingent of co-owners (in houses where people of pre-retirement and retirement age mostly live, the main attention is paid to financial indicators of management - the cost of management, repair costs, etc.; in new buildings more attention is paid to the development of adjacent infrastructure (improving communications, participation in local programs, etc.);

- the number of co-owners of an apartment building (the greater the number of co-owners, the smaller the financial burden in the process of current and capital repairs, infrastructure development of the adjacent territory, etc.); 
- date of commissioning of the housing stock (old housing stock requires significant financial investments in the repair of plumbing, power lines, etc., while new buildings require playgrounds, recreation areas for co-owners, landfills, etc.).

\section{The parameters for evaluating the effectiveness of apartment building management}

The analysis of economic efficiency and social responsibility should consider that the management system should be aimed at achieving the following goals of apartment building management:

1) economical goal, which on the part of the co-owners of an apartment building should ensure the efficient use of consumer funds aimed at maintaining and improving the housing stock, while on the part of the manager his or her production activities for the provision of management services should be profitable;

2) social goal - maximum satisfaction of consumer needs of co-owners;

3) technological goal - maintenance and improvement of the technical condition of the apartment building, therefore, in parallel with economic efficiency and social responsibility, the technical consequences of management activities should be considered and evaluated.

In the development of this approach as target criteria of efficiency of management of the apartment house we can use the following:

- safety (level of protection of a person and his property from fire, accident, accident, natural and man-made threats);

- level of comfort (compliance of living with the existing set of requirements, which provides the optimal living environment for co-owners);

- level of reliability (in the ability of the object to preserve the basic characteristics of the housing stock during its operation);

- level of availability (level of possibility of acquisition of housing by individuals in accordance with their values, needs and income level).

In our opinion, in the proposed model it is important to define individual indicators of service quality, which are characterized as the ratio of subjective/objective quality indicator of apartment building management to the reference value of the corresponding subjective or objective quality indicators of management.

Therefore, it can be argued that the effectiveness of apartment building management should include an analysis of the broadest list of indicators, so the main criteria for assessing the effectiveness of management of apartment buildings are as follows (Table 1).
In order to assess the effectiveness of the management of an apartment building, a 5-point system is used according to the following principle:

5 points indicate the full compliance of management activities with current rules and regulations (excellent quality of work and services, which is assessed using certain indicators);

4 points indicate sufficient compliance of management activities with the established indicators and basic parameters (indicate good quality);

3 points allow us to talk about the average level of compliance with the rules and regulations for the management of an apartment building according to the basic parameters (you can see a satisfactory level of management services);

2-0 points indicate extremely low compliance with current norms and rules or its absence (in this case, management activities deserve an unsatisfactory assessment of the quality of work).

After summing the scores separately for each criterion, you can also apply the coefficient of significance of each parameter and determine the final assessment of the effectiveness of apartment building management, and, in our opinion, the level of significance of each criterion should be set by each apartment building in accordance with management base etc.

\section{Conclusions}

The evaluation of the effectiveness of the management of an apartment building should be carried out periodically with the obligatory accompaniment of surveys of co-owners. Thus, consider that the effectiveness of management from the standpoint of achieving goals and the level of effectiveness of management measures. Therefore, we believe that the results of the evaluation of management activities should be an incentive for their activities. Management activities must be transparent and efficient.

It is worth noting that in light of recent trends, the assessment of the effectiveness of management of apartment buildings should take into account the following criteria and indicators:

1) energy efficiency:

- issues of technical operation and maintenance of apartment buildings;

- rational energy consumption;

- use of energy saving technologies;

- reduction of costs for electricity, heat supply;

2) environmental indicators:

- reduction of negative impact on the environment;

- improving waste management;

- ensuring periodic garbage removal by relevant companies;

- ensuring the cleanliness of the adjacent territory;

3) social dimension: 
Table 1

\begin{tabular}{|c|c|}
\hline Groups of indicators & Indicators \\
\hline 1 & 2 \\
\hline $\begin{array}{l}\text { Availability of technical } \\
\text { documentation for an apartment } \\
\text { building, as well as its condition and } \\
\text { completeness of the list }\end{array}$ & $\begin{array}{l}\text { - executive management documentation for the house; } \\
\text { - documentation related to the technical accounting of the housing stock, which contains } \\
\text { information on the condition of the common property; } \\
\text { - cadastral documents }\end{array}$ \\
\hline $\begin{array}{l}\text { Maintaining documents for the } \\
\text { management of an apartment } \\
\text { building on the issues of current } \\
\text { maintenance and repair }\end{array}$ & $\begin{array}{l}\text { - proper documentation on the inspection of the housing stock and its condition in the relevant } \\
\text { seasons; } \\
\text { - documentation of readiness of housing for seasonal operation; } \\
\text { - documents-plans for maintenance of common property; } \\
\text { - documents on the implementation of plans for maintenance; } \\
\text { - plan for overhaul of common property; } \\
\text { - documentation on the level and performance indicators of the plan of overhaul of common } \\
\text { property; } \\
\text { - the decision of the co-owners of the apartment building to approve estimates for maintenance and } \\
\text { overhaul of the apartment building; } \\
\text { - accepted (approved) and executed schedules of regular inspections of the apartment building and } \\
\text { adjacent territories, documented inspection results; } \\
\text { - indicators of timely implementation of measures to maintain order and insurance of housing with } \\
\text { significant depreciation }\end{array}$ \\
\hline $\begin{array}{l}\text { Indicators of quality of maintenance, } \\
\text { repair and development of } \\
\text { infrastructure (adjacent territory) }\end{array}$ & $\begin{array}{l}\text { - current condition of garbage containers, schedule of their cleaning, observance of schedules; } \\
\text { - current condition of lawns and green areas located in the surrounding area; } \\
\text { - approved and implemented plans for landscaping and landscaping of the adjacent territory; } \\
\text { - current condition of outdoor lighting (operation, appearance, safety, energy efficiency, performance } \\
\text { of assigned functions); } \\
\text { - the current condition of the territories set aside for drying clothes, recreation of citizens; } \\
\text { - sports, playgrounds: their availability, condition, development; } \\
\text { - seasonal grounds (summer, winter); } \\
\text { - current condition of sanitary condition of garbage pipes, elevators, common corridors, stairwells; } \\
\text { - approved and executed schedules of sanitary cleaning of public premises in accordance with } \\
\text { regulatory documents; } \\
\text { - sanitary condition of basements; } \\
\text { - sanitary condition of the attic of an apartment building, the existence of fire hydrants, their } \\
\text { condition and suitability for use; } \\
\text { - the presence of fire shields, their condition; }\end{array}$ \\
\hline $\begin{array}{l}\text { Indicators of the quality of services } \\
\text { provided to co-owners }\end{array}$ & $\begin{array}{l}\text { - the existence of a list of agreements with organizations that supply heat, water, gas, electricity, } \\
\text { garbage, provide homophone services, etc.; } \\
\text { - substantiated claims of co-owners of an apartment building for the absence or low quality of } \\
\text { provided utilities (during a certain period - a quarter, six months, a year); } \\
\text { - the number of detected emergencies in the life support systems of an apartment building, which } \\
\text { were eliminated in violation of certain deadlines (during a certain period - a quarter, six months, a } \\
\text { year); } \\
\text { - applications of co-owners of an apartment building, which were executed in violation of the } \\
\text { established deadlines (during a certain period - a quarter, six months, a year); } \\
\text { - organization of the general meeting of co-owners of an apartment building; } \\
\text { - the quality of decision-making specified in time of the meeting; } \\
\text { - duration of management decisions; } \\
\text { - support of management decisions made by co-owners }\end{array}$ \\
\hline $\begin{array}{l}\text { Financial and economic indicators } \\
\text { of management }\end{array}$ & $\begin{array}{l}\text { - condition, level, dynamics of indebtedness of co-owners for payment of utilities and management } \\
\text { services; } \\
\text { - arrears of management services (salary); } \\
\text { - availability, size and dynamics of the reserve fund; } \\
\text { - availability and features of investment programs (deposit accounts); } \\
\text { - the dependence of the dynamics of the size of management costs of co-owners and their ability to } \\
\text { pay utility bills on time (ie the validity of the established prices for apartment building management } \\
\text { services, the optimal financial burden on co-owners taking into account the number of state } \\
\text { subsidies) }\end{array}$ \\
\hline Quality of the management staff & - quality of the management staff \\
\hline Quality of the management activity & - quality of the management activity \\
\hline
\end{tabular}


- ensuring the rights of co-owners to receive quality services;

- participation of co-owners in the management of the house;

- the right chairman of each co-owner;

4) loyalty of co-owners:

- periodic meetings;

- general participation in management decisions;

- possibility to get acquainted with documents on house management;

- effective communications with the management of the apartment building;

5) communication with state local authorities, etc.: - participation in local development programs;

- receiving state support, etc.

It should also be noted that the assessment of the effectiveness of apartment building management can be initiated by the general meeting of building co-owners, the initiative group, the chairman of the association of co-owners of an apartment building (ACAB) and carried out by creating a commission consisting of both co-owners and representatives of the apartment building management body. Based on the results of such an assessment, an appropriate decision is made to overcome existing problems or find new ways and opportunities to improve the management mechanism of the apartment building.

Thus, according to the results of the study, we note that since a single method of analyzing the effectiveness of apartment building management in Ukraine has not yet been developed, co-owners and representatives of building management bodies at their discretion create appropriate algorithms for such assessment.

\section{References:}

Alekseev, I. V., \& Moroz, N. V. (2016). Evaluating the effectiveness of housing management. Current economic problems. Series "Demography, labor economics, social economy and politics, vol. 5(179), pp. 246-253.

Moroz, N. V., Bondarenko, L. P., \& Chubka, O. M. (2018). Principles of professional management of multiapartment buildings. Scientific Bulletin of Polissia, vol. 2(14), part 1, pp. 150-156. 